\title{
Pengaruh Media Pembelajaran Berbasis Android terhadap Kemampuan Memahami Teks Prosedur Siswa Kelas VII
}

\author{
Giri Indra Kharisma \\ Universitas Timor \\ indrakharisma@unimor.ac.id
}

DOI: https://doi.org/10.32528/bb.v5i2.2795

First received: 22-12-2019 Final proof received: 29-09-2020

\begin{abstract}
ABSTRAK
Salah satu komponen penting dalam menentukan keberhasilan pembelajaran yakni media pembelajaran. Penggunaan media pembelajaran perlu disesuaikan dengan perkembangan ilmu pengetahuan dan teknologi. Media pembelajaran yang digunakan dalam penelitian ini berupa aplikasi android yang dapat diakses melalui gawai siswa. Aplikasi tersebut berisi materi dan latihan memahami struktur dan ciri kebahasaan teks prosedur. Aplikasi media pembelajaran ini diharapkan mampu membantu siswa dalam memahami konsep teks prosedur, membangkitkan minat, motivasi, dan rangsangan belajar siswa. Selain itu, media pembelajaran ini juga bertujuan untuk memudahkan siswa dalam mengakses materi ajar dimanapun dan kapanpun serta dapat memfasilitasi siswa belajar dengan teman atau guru melalui jejaring sosial. Penelitian ini bertujuan untuk mengetahui pengaruh media pembelajaran berbasis android terhadap kemampuan siswa dalam menentukan stuktur dan ciri kebahasaan teks prosedur. Subjek dalam penelitian ini yakni siswa kelas VII MTS Nurul Falah yang berjumlah 27 orang. Metode yang digunakan dalam penelitian ini yakni metode eksperimen semu (quasi experiment) dengan jenis rancangan berupa pretespostes kelompok tunggal (tanpa kelas kontrol). Berdasarkan hasil penelitian, diketahui bahwa aplikasi pembelajaran berbasis android memberikan pengaruh yang lebih baik terhadap kemampuan siswa dalam menentukan struktur dan ciri kebahasaan teks prosedur. Hal tersebut tampak dari hasil uji beda antara nilai rata-rata pretest sebesar 74,3 dengan nilai rata-rata posttest sebesar 86,1.
\end{abstract}

Kata Kunci: Media Pembelajaran; Aplikasi Android; Teks Prosedur

\begin{abstract}
Learning media is an important component in determining learning success. The use of instructional media needs to be adjusted to the development of science and technology. The learning media used in this study are android applications that can be accessed through student devices. The application contains material and exercises to understand the structure and linguistic characteristics of the procedure text. This learning media application is expected to be able to help students understand the concept of the procedure text, arouse interest, motivation, and stimulate student learning. In addition,
\end{abstract}


this learning media also aims to facilitate students in accessing teaching material wherever and whenever and can facilitate students learning with friends or teachers through social networks. This study aims to determine the effect of Android-based learning media on the ability of students to determine the structure and characteristics of procedure text. The subjects in this study were students of class VII MTS Nurul Falah, amounting to 27 students. The method used in this research is quasi-experimental method with a type of design in the form of single group pre-test (without control class). Based on the results of the study, it is known that the Android-based learning application gives a better influence on the ability of students to determine the structure and characteristics of procedure text. This is evident from the results of the test difference between the average pretest value of 74.3 with an average posttest value of 86.1.

\section{Keywords: Learning Media; Android Aplication; Procedure Text}

\section{PENDAHULUAN}

Konsep pembelajaran saat ini telah bergeser pada upaya perwujudan pembelajaran yang modern seiring dengan perkembangan zaman dan era globalisasi. Tuntutan masyarakat yang semakin besar terhadap pembelajaran serta kemajuan ilmu pengetahuan dan teknologi, membuat pembelajaran tidak mungkin lagi dikelola secara tradisional. Perkembangan teknologi informasi dan komunikasi (TIK), gaya hidup masyarakat, pola baru dalam belajar anak, dan lain sebagainya menuntut adanya langkah dalam memanfaatkan teknologi dalam pembelajaran. Menurut Traxler (2005), teknologi informasi dan komunikasi dapat menjadikan proses pembelajaran lebih menarik, terbuka, dan fleksibel karena tidak dibatasi oleh ruang dan waktu.

Teknologi pembelajaran mempunyai karakteristik tertentu yang sangat relevan bagi kepentingan pembelajaran. Teknologi pembelajaran memungkinkan adanya: (1) informasi yang tersampaikan secara luas, cepat, merata, terintegrasi, dan sesuai dengan isi yang dimaksud, (2) teknologi pembelajaran dapat menyajikan materi secara ilmiah, logis, dan sistematis serta mampu menjadi penunjang dan pelengkap materi pelajaran, (3) teknologi pembelajaran dapat menjadi partner guru dalam menciptakan kegiatan pembelajaran yang efektif, efisien, dan produktif berdasarkan kebutuhan dan tuntutan siswa, (4) teknologi pembelajaran dapat digunakan sebagai sumber belajar yang menyajikan materi secara lebih menarik (Danim, 2008:3-4).

Keberadaan pembelajaran berbasis TIK telah menjadi tuntutan pembelajaran abad 21. Pembelajaran abad 21 menuntut siswa memiliki pengetahuan dan keterampilan yang memadai sesuai dengan dinamika perkembangan globalisasi. Sutrisno (2005:12) menjelaskan bahwa keterampiran yang dimaksud yakni keterampilan berkomunikasi, berkolaborasi, berpikir kreatif dan kritis, berusaha memecahkan masalah, dan bertanggung jawab terhadap pribadi maupun sosial. Dalam pembelajaran abad 21, siswa juga dituntut mampu menguasai teknologi informasi dan komunikasi agar memperoleh informasi dari berbagai sumber serta mampu bekerja sama dengan individu lain maupun kelompok.

Pemanfaatan teknologi informasi dan komunikasi dalam pembelajaran juga dapat diwujudkan ke dalam bentuk media pembelajaran. Media pembelajaran merupakan 
salah satu komponen penting dalam menentukan keberhasilan pembelajaran. Media pembelajaran merupakan sarana yang digunakan oleh siswa dalam memperoleh pengetahuan, keterampilan, ataupun sikap (Amirullah \& Hardinata, 2017). Dalam proses pembelajaran, segala sesuatu yang dapat dimanfaatkan untuk menyampaikan pesan atau materi ajar dan dapat merangsang perhatian, minat, pikiran dan perasaan siswa dalam kegiatan belajar guna mencapai tujuan belajar disebut sebagai media pembelajaran (Arsyad, 2011:15).

Penggunaan media pembelajaran sebaiknya beriringan dengan perkembangan ilmu pengetahuan dan teknologi. Semakin berkembangnya ilmu pengetahuan dan teknologi, semakin mendorong upaya-upaya pembaharuan dalam menciptakan dan memanfaatkan media pembelajaran (Kharisma \& Arvianto, 2019). Dengan adanya pembaharuan tersebut, kegiatan pembelajaran akan lebih menarik. Oleh sebab itu, para guru dituntut mampu menciptakan dan memanfaatkan media pembelajaran yang sesuai dengan perkembangan dan tuntutan zaman.

Di era modernisasi saat ini, teknologi di bidang telekomunikasi mengalami perkembangan pesat, khususnya di Indonesia. Berbagai perangkat telekomunikasi, khususnya smartphone dan tablet, tersebar di seluruh Indonesia. Pertiwi (2019) menuliskan bahwa badan riset pasar Canalys mencatat sepanjang 2018, pertumbuhan pengapalan smartphone di Indonesia mencapai 17,1\% dibanding tahun 2017. Jumlah smartphone yang dikapalkan di tanah air selama tahun 2018 mencapai 38 juta. Sementara pada kuartal ke empat pada 2018, jumlah pengiriman smartphone mencapai 9,5 juta unit, naik 8,6 persen secara year-on-year (YoY). Berdasarkan data tersebut, maka dapat diperkirakan bahwa teknologi komunikasi, khususnya smartphone dan tablet, masih akan terus berkembang dari tahun ke tahun.

Pembelajaran bahasa dan sastra Indonesia (PBSI) dalam Kurikulum 2013 dirancang sebagai pembelajaran yang berbasis teks. Teks dipandang mampu merefleksikan situasi dalam pemakaian bahasa yang ada di sekitar siswa (Kharisma, 2019). Awalnya siswa dilatih untuk memahami berbagai teks hingga kemudian memproduksinya. Setelah memproduksi teks tersebut, siswa diharapkan mampu mempraktikkannya dalam berbagai kegiatan berbahasa di kehidupan sehari-hari sesuai dengan tujuan sosial dan konteks situasinya.

Salah satu teks yang menjadi materi dalam kurikulum 2013 adalah teks prosedur. Teks prosedur pada dasarnya digolongkan ke dalam teks faktual yang bertujuan untuk memberikan informasi. Menurut Anderson dan Kathy (2003:28), teks prosedur merupakan teks yang bertujuan untuk memberikan informasi kepada pembaca atau pendengar tentang cara membuat sesuatu atau melakukan sesuatu. Melalui teks prosedur, siswa dapat melatih kemampuan kognitifnya. Hal tersebut diutarakan oleh Knapp dan Megan (2005:155) yang menjelaskan bahwa salah satu keterampilan kognitif awal anak-anak berkembang adalah kemampuan dalam mengurutkan.

Pembelajaran menentukan strukur dan ciri kebahasaan teks prosedur merupakan pembelajaran yang sangat penting karena menjadi dasar untuk pembelajaran menulis teks prosedur. Siswa akan mampu menyusun teks prosedur dengan baik dan benar, jika siswa memahami karakteristik teks prosedur. Memahami teks prosedur merupakan 
kompetensi yang harus dikuasai oleh siswa kelas VII SMP sebagaimana tercantum dalam Kompetensi dasar 3.6 Menelaah struktur dan aspek kebahasaan teks prosedur tentang cara melakukan sesuatu dan cara membuat (cara memainkan alat music atau tarian daerah, cara membuat kuliner khas daerah, dll.) dari berbagai sumber yang dibaca dan didengar. Kompetensi dasar tersebut menuntut siswa untuk mampu menentukan struktur dan ciri kebahasaan teks prosedur.

Untuk mengetahui kemampuan awal siswa dalam menentukan struktur dan ciri kebahasaan teks prosedur, kegiatan prapenelitian telah dilakukan oleh peneliti kepada 27 siswa kelas VII MTs Nurul Falah. Hasil dari prapenelitian menunjukkan bahwa masih banyak siswa yang tidak paham tentang teks prosedur. Kebanyakan siswa masih kesulitan memahami unsur kebahasaan yang terdapat dalam teks prosedur. Hal tersebut didukung dengan perolehan rata-rata nilai siswa yang mencapai 74,14 . Dari rata-rata nilai tersebut, terdapat 10 siswa yang memperoleh nilai di bawah Kriteria Ketuntasan Minimal (KKM). Dari hasil prapenelitian juga diketahui bahwa guru menggunakan media pembelajaran berupa gambar dalam mengajarkan struktur dan ciri kebahasaan teks prosedur. Akibatnya, pembelajaran menjadi kurang interaktif sehingga hasil belajar siswa menjadi kurang maksismal.

\section{METODE PENELITIAN}

Metode yang digunakan dalam penelitian ini yakni metode eksperimen semu (quasi experiment) dengan jenis rancangan berupa pretes-postes kelompok tunggal (tanpa kelas kontrol). Rancangan penelitian tersebut bertujuan untuk mengetahui efek sebelum dan sesudah pemberian perlakuan. Adapun kegiatannya terbagi menjadi tiga langkah, yaitu, (1) melaksanakan pretest, (2) melaksanakan perlakuan, dan (3) melaksanakan posttest. Berikut ini adalah desain eksperimen yang dilakukan.

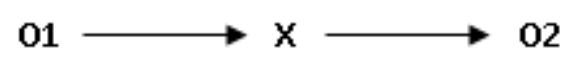

Keterangan

O1 : pretes

$\mathrm{X}:$ perlakukan (treatment)

$\mathrm{O} 2:$ postes

Penelitian ini bertujuan untuk mengetahui pengaruh aplikasi pembelajaran berbasis android terhadap kemampuan siswa dalam menentukan stuktur dan ciri kebahasaan teks prosedur. Oleh sebab itu, variabel bebas dalam penelitian ini yakni penggunaan aplikasi pembelajaran berbasis android, sedangkan variabel terikatnya berupa kemampuan siswa dalam menentukan struktur dan ciri kebahasaan teks prosedur. Subjek dalam penelitian ini yakni siswa kelas VII MTS Nurul Falah yang berjumlah 27 Siswa.

Teknik pengumpulan data yang digunakan dalam penelitian ini berupa tes. Tes dilakukan dengan cara memberikan soal pre-test dan post test. Tes yang diberikan berupa 20 soal pilihan ganda dan 5 soal essai. Tes diberikan untuk mengetahui 
perbedaan hasil kemampuan siswa dalam menentukan struktur dan ciri kebahasaan teks prosedur sebelum dan sesudah menggunakan aplikasi pembelajaran berbasis android.

Data yang diperoleh dalam penelitian ini dianalisis dengan uji Wilcoxon yaitu dengan mencari perbedaan mean pretest dan posttest. Pelaksanaan uji Wilcoxon dilakukan dengan bantuan progam SPSS 22 for Windows.

\section{PEMBAHASAN}

Pada awalnya, 27 siswa kelas VII MTS Nurul Falah diminta untuk mengerjakan soal pre-test untuk mengetahui kemampuan mereka dalam menentukan struktur dan ciri kebahasaan teks prosedur. Sebelum pre-test dilakukan, siswa dijelaskan tentang struktur dan ciri kebahasaan teks prosedur menggunakan media pembelajaran berupa tayangan powerpoint dan gambar. Setelah pre-test dilakukan, siswa kembali dijelaskan tentang struktur dan ciri kebahasaan teks prosedur. Cuma kali ini, media pembelajaran yang digunakan yakni aplikasi pembelajaran berbasis android. Setelah siswa belajar teks prosedur menggunakan aplikasi pembelajaran berbasis android, siswa diberi post test dengan mengerjakan 20 soal pilihan ganda dan 5 soal essai. Berikut pemaparan hasil pre-test dan post test siswa pada tabel 1.

Tabel 1. Hasil Pre Test dan Post Test

\begin{tabular}{cccc|cccc}
\hline NO. & Nama Siswa & Pretest & Posttest & NO. & Nama Siswa & Pretest & Posttest \\
\hline 1. & ARQ & 80 & 90 & 16. & NPK & 80 & 87,5 \\
\hline 2. & AS & 75 & 82,5 & 17. & NAH & 70 & 97,5 \\
\hline 3. & ANM & 70 & 77,5 & 18. & QIS & 75 & 72,5 \\
\hline 4. & DBU & 70 & 85 & 19. & RO & 70 & 85 \\
\hline 5. & DS & 75 & 85 & 20. & MDK & 80 & 85 \\
\hline 6. & DAK & 75 & 82,5 & 21. & MRO & 75 & 80 \\
\hline 7. & DAR & 85 & 97,5 & 22. & RIR & 70 & 85 \\
\hline 8. & F & 70 & 85 & 23. & SN & 75 & 92,5 \\
\hline 9. & IN & 75 & 97,5 & 24. & SNA & 70 & 97,5 \\
\hline 10. & LNR & 70 & 77,5 & 25. & TH & 80 & 85 \\
\hline 11. & MPM & 72 & 80 & 26. & VDP & 70 & 92,5 \\
\hline 12. & MI & 75 & 80 & 27. & ZI & 75 & 85 \\
\hline 13. & MDH & 70 & 85 & \multicolumn{5}{|c}{} \\
\hline 14. & MT & 70 & 85 & \multicolumn{5}{c}{} \\
\hline 15. & NNI & 80 & 90 & \multicolumn{5}{c}{} \\
\hline
\end{tabular}

Setelah data pre test dan post test diperoleh, tahap selanjutnya yakni uji normalitas data yang dilakukan dengan menggunakan One-Sample KolmogorovSmirnov Test. Hasil dari uji tersebut digunakan untuk menentukan teknik uji beda yang digunakan. Tabel 2 merupakan hasil uji normalitas data pretest dan posttest siswa. 
Tabel 2. Hasil Uji Normalitas Data

\begin{tabular}{llll}
\hline \multicolumn{4}{c}{ One-Sample Kolmogorov-Smirnov Test } \\
\hline $\mathrm{N}$ & & Nilai pretest & Nilai posttest \\
\hline Normal Parameters ${ }^{\mathrm{a}, \mathrm{b}}$ & 27 & 27 \\
\hline & Mean & 74.1481 & 86.1111 \\
\hline Most Extreme Differences & Std. Deviation & 4.33859 & 6.55353 \\
\hline & Absolute & .238 & .234 \\
\cline { 2 - 4 } & Positive & .238 & .234 \\
\cline { 2 - 4 } & Negative & -.170 & -.136 \\
\hline Test Statistic & .238 & .234 \\
\hline Asymp. Sig. (2-tailed) & $.000^{\mathrm{c}}$ & $.001^{\mathrm{c}}$ \\
\hline a. Test distribution is Normal. \\
\hline b. Calculated from data. \\
\hline c. Lilliefors Significance Correction. \\
\hline
\end{tabular}

Berdasarkan tabel hasil uji normalitas di atas, diketahui bahwa semua data pretest dan post test tidak terdistribusi normal. Hal tersebut tampak dari nilai Asymp. Sig. (2-Tailed) yang lebih kecil atau kurang dari 0,05. Oleh sebab itu, teknik uji beda dilakukan dengan menggunakan uji Wilcoxon. Tabel 3 merupakan hasil dari uji beda yang dilakukan.

Tabel 3. Hasil Statistik Uji Beda Nilai Pre Test dan Post Test

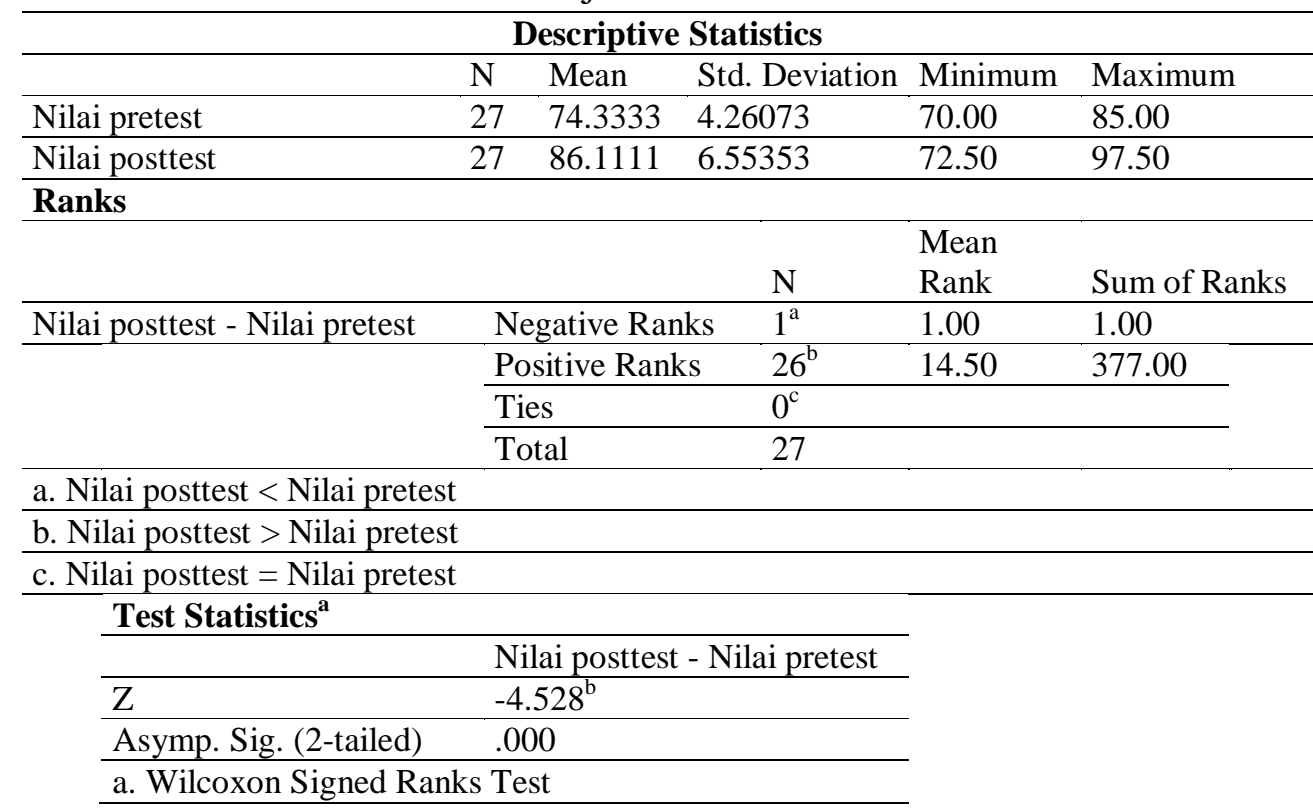

Dari hasil statistik uji beda, dapat diketahui bahwa ada seorang siswa yang memiliki nilai posttest lebih kecil dari nilai pretest dan ada 26 siswa yang memiliki nilai posttest lebih besar dari nilai pretest. Hal tersebut mengindikasikan bahwa banyak siswa yang mampu mendapatkan hasil lebih baik setelah menggunakan aplikasi pembelajaran berbasis android untuk kompetensi menentukan struktur dan ciri kebahsaan teks prosedur.

Pada tabel di atas juga tampak jumlah nilai rata-rata pretest sebesar 74,3333 dengan SD 4,26073, sedangkan nilai rata-rata posttest sebesar 86,1111 dengan SD 6,55353. Hal tersebut menunjukkan bahwa nilai rata-rata pretest lebih kecil daripada 
nilai rata-rata posttest sehingga dapat disimpulkan bahwa terdapat perbedaan yang signifikan antara kemampuan siswa sebelum dan sesudah perlakuan karena $\mathrm{P}<\alpha 0,05$. Artinya, terdapat peningkatan nilai siswa dalam menentukan struktur dan ciri kebahasaan teks prosedur setelah menggunakan aplikasi pembelajaran berbasis android.

Pemanfaatan aplikasi android dalam pembelajaran teks prosedur merupakan bentuk implementasi dari pembelajaran berbasis mobile. Nordin, Embi, \& Yunus (2010) mengatakan bahwa mobile learning merupakan pembelajaran yang memanfaatkan mobile device atau handheld technology seperti handphone, PDA, IPod, Pocket PC, dan semua produk teknologi yang menunjang pembelajaran yang bisa dibawa ke mana saja dan dapat digunakan di mana saja. Melalui aplikasi pembelajaran ini, siswa dapat mengakses materi dan latihan yang berkaitan dengan pembelajaran kapanpun dan di manapun. Hal tersebut tentu saja telah memberikan sebuah pengalaman baru yang menarik dan menyenangkan bagi siswa. Siswa tidak lagi terus-menerus berkutat dengan buku pelajaran atau bertatap muka langsung dengan guru sebagaimana yang sudah sering terjadi pada pembelajaran sebelumnya.

Aplikasi pembelajaran berbasis android ini juga mempermudah interaksi antara siswa dengan materi pelajaran, siswa dengan guru, maupun antarsiswa karena adanya fitur grup facebook yang diintegrasikan ke dalam aplikasi ini. Mereka dapat saling berbagi informasi atau berdiskusi tentang materi pelajaran melalui aplikasi tersebut tanpa harus bertatap muka secara langsung. Guru dapat pula mengunggah materi pelajaran melalui grup facebook tersebut yang nantinya dapat diunduh oleh para siswa. Guru juga dapat memberikan tugas atau kuis secara daring melalui fitur quizizz dengan waktu pengumpulan yang telah ditentukan. Nantinya siswa dapat langsung mengerjakan melalui smartphone mereka dengan cara mengakses tautan yang telah dibagikan oleh guru. Setelah mengerjakan, guru dan siswa dapat langsung mengetahui hasilnya tanpa harus lama menunggu. Selain fitur grup facebook dan quizizz, terdapat pula fitur Youtube yang digunakan untuk menampilkan video contoh prosedur. Fitur lain yakni KBBI daring digunakan untuk membantu siswa dalam mencari makna dari istilah sulit yang terdapat pada teks prosedur.

Adanya dampak positif yang terlihat dari peningkatan hasil belajar siswa dalam memahami teks prosedur menunjukkan bahwa aplikasi pembelajaran ini memang memiliki kelebihan dalam menunjang aktivitas belajar siswa. Hal ini sesuai dengan pendapat Sharples \& Pea (2014) yang mengatakan bahwa melalui kegiatan mobile learning, fleksibilitas belajar siswa menjadi lebih tinggi karena siswa dapat mengakses materi belajar dan mengkomunikasikannya dengan guru kapanpun dan di manapun. Dengan kondisi yang demikian ini, pembelajaran menjadi lebih efektif dan efisien. Hasil penelitian ini selaras dengan hasil penelitian sebelumnya yang juga ingin mengetahui dampak media pembelajaran berbasis android terhadap mata pelajaran atau materi tertentu, seperti halnya yang telah dilakukan oleh Lubis \& Ikhsan (2015), Prasetyo, Yektyastuti, Solihah, Ikhsan, \& Sugiyarto (2015), dan Ramansyah (2015).

Dibalik dampak positif dari aplikasi pembelajaran berbasis android, terdapat beberapa kendala atau kekurangan yang ditemukan dalam penelitian ini. Terdapat beberapa siswa yang kesulitan mengakses aplikasi karena spesifikasi smartphone yang 
digunakan tidak memadai dalam menggunakan aplikasi ini. Selain itu, aplikasi ini membutuhkan akses internet dalam penggunaannya sehingga siswa perlu memiliki pulsa atau paket data.

\section{SIMPULAN}

Berdasarkan temuan dari hasil penelitian, dapat ditarik kesimpulan bahwa aplikasi pembelajaran berbasis android memberikan pengaruh yang lebih baik terhadap kemampuan siswa dalam menentukan struktur dan ciri kebahasaan teks prosedur. Hal tersebut tampak dari hasil uji beda antara nilai rata-rata pretest sebesar 74,3 dengan nilai rata-rata posttest sebesar 86,1 .

Sasaran dari aplikasi pembelajaran ini adalah siswa dan guru Bahasa Indonesia kelas VII SMP/MTs yang memiliki smartphone atau tablet. Akan tetapi, tidak menutup kemungkinan bahwa pengguna smartphone atau tablet selain siswa dan guru juga dapat menggunakan bahan media pembelajaran ini karena aktivitas belajar dapat dilakukan oleh siapapun (khususnya berkaitan dengan teks prosedur). Bagi siswa, aplikasi pembelajaran ini dapat memfasilitasi mereka untuk memahami konsep teks prosedur yang meliputi isi, struktur, ciri kebahasaan teks prosedur. Sementara bagi guru, aplikasi pembelajaran ini dapat dimanfaatkan sebagai sarana pendukung dalam pembelajaran teks prosedur. Guru juga dapat memanfaatkan aplikasi pembelajaran ini untuk membuat pembelajaran menjadi lebih menarik sehingga mampu membangkitkan minat, motivasi, dan mengarahkan perhatian siswa. Materi yang disajikan dalam media pembelajaran ini juga dapat dimanfaatkan oleh guru untuk melengkapi materi ajar teks prosedur yang terdapat dalam buku ajar kelas VII SMP/MTs.

\section{DAFTAR RUJUKAN}

Amirullah, G., \& Hardinata, R. (2017). Pengembangan Mobile Learning bagi Pembelajaran. JKKP (Jurnal Kesejahteraan Keluarga Dan Pendidikan). https://doi.org/10.21009/jkkp.042.07

Anderson, M., \&Anderson, K. (2003). Teks Types in English 2. National Library of Australia.

Arsyad, A. (2011). Media Pembelajaran. Jakarta: Raja Grafindo Persada.

Danim, Sudarwan. 2008. Media Komunikasi Pendidikan. Jakarta: Bumi Aksara.

Kharisma, G.I. (2019). Model Pembelajaran Tim game Turnament (TGT) Plus untuk Pembelajaran Teks Eksposisi. Metalingua: Jurnal Pendidikan Bahasa dan Sastra Indonesia. 4(1). 1-6.

Kharisma, G. I., \& Arvianto, F. (2019). Pengembangan aplikasi android berbentuk education games berbasis budaya lokal untuk keterampilan membaca permulaan bagi siswa kelas 1 SD/MI. Premiere Educandum: Jurnal Pendidikan Dasar Dan Pembelajaran. https://doi.org/10.25273/pe.v9i2.5234

Knapp, P., \& Watkins, M. (2005). Genre, Text, Grammar Technologies for Teaching and Assessing Writing. Sidney: University of New South Wales Press Ltd.

Lubis, I. R., \& Ikhsan, J. (2015). Pengembangan Media Pembelajaran Kimia Berbasis Android untuk Meningkatkan Motivasi Belajar dan Prestasi Kognitif Peserta 
Didik SMA. Jurnal Inovasi Pendidikan IPA. https://doi.org/10.21831/jipi.v1i2.7504

Nordin, N., Embi, M. A., \& Yunus, M. M. (2010). Mobile learning framework for lifelong learning. In Procedia - Social and Behavioral Sciences. https://doi.org/10.1016/j.sbspro.2010.10.019

Pertiwi, W.K. (2019). 2018, Pasar Smartphone Indonesia Tumbuh Dua Digit. Diakses pada $14 \quad$ Agustus 2019, dari https://tekno.kompas.com/read/2019/03/01/16160037/2018-pasarsmartphone-indonesia-tumbuh-dua-digit?page=all.

Prasetyo, Y. D., Yektyastuti, R., Solihah, M., Ikhsan, J., \& Sugiyarto, K. H. (2015). Pengaruh Penggunaan Media Pembelajaran Kimia Berbasis Aandroid Terhadap Peningkatan Motivasi Belajar Siswa SMA. Seminar Nasional Pendidikan Sains.

Ramansyah, W. (2015). Pengembangan Education Game (Edugame ) Berbasis Android Pada Mata Pelajaran Bahasa Inggris Untuk Peserta Didik Sekolah Dasar. Jurnal Ilmiaah Edutic.

Sharples, M., \& Pea, R. (2014). Mobile learning. In The Cambridge Handbook of the Learning Sciences, Second Edition. https://doi.org/10.1017/CBO9781139519526.030

Sutrisno. 2005. Revolusi Pendidikan di Indonesia: Membedah Metode dan Teknik Pendidikan Berbasis Kompetensi. Yogyakarta: Ar Ruzz.

Traxler, J. (2005). Defining mobile learning. IADIS International Conferense Mobile Learning.261-266 
